\title{
SWIMMING AND BONE MINERAL DENSITY: A SPORT WITHOUT OSTEOGENIC STIMULATION?
}

NATAÇÃO EDENSIDADE MINERAL ÓSSEA: UMA MODALIDADE ESPORTIVA SEM ESTÍMULO OSTEOGÊNICO?

NATACIÓN Y DENSIDAD MINERAL ÓSEA: ¿UNA MODALIDAD DEPORTIVA SIN ESTÍMULOOSTEOGÉNICO?

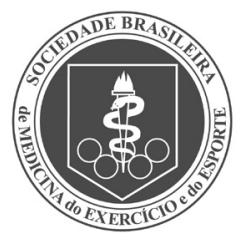

Original Article

Artigo OrIGINAL Artículo Original
Rodrigo Barbosa de

Albuquerque ${ }^{1,2,3,6}$ (iD)

(Physical Education Professional)

Amandio Aristides Rihan Geraldes 2,3 (ID (Physical Education Professional)

Bruno Rangoussis 4 (DD

(Physical Education Professional)

Fabiano de Souza Fonseca ${ }^{5}$ (DD

(Physical Education Professional)

Deocleciano de Carvalho

Nascimento Neto $^{6}$ (D)

(Final-Year Physical Education

Student)

Antônio César Cabral de Oliveira' (ID (Physical Education Professional)

1. Universidade Federal de Sergipe (UFS), Aracaju, SE, Brazil.

2. Universidade Federal de Alagoas (UFAL), Maceió, AL, Brazil.

3. Universidade Federal de Alagoas (UFAL), Laboratório de Aptidão

Física, Desempenho e Saúde

(LAFIDES), Maceió, AL, Brazil.

4. Instituto Batista de Ensino

Superior de Alagoas, Maceió,

AL, Brazil.

5. Universidade Federal Rural de Pernambuco (UFRPE), Pernambuco, PE, Brazil.

6. Universidade Federal de Alagoas (UFAL), Research Group in Sciences Applied to Sport (GPCAE), Maceió, AL, Brazil.

\section{Correspondence:}

Rodrigo B. de Albuquerque. Rua B, Residencial Jardim Santa Ana, 22, Quadra B, Serraria, Maceió, Alagoas, AL, Brazil. 57046-802. rodrigoalbuquerque_1@hotmail.com

\begin{abstract}
Introduction: The osteogenic effects generated by different sports are the subject of a growing number of research projects. Regular physical activity is one of the main recommendations for the stimulation of bone mineral density (BMD). However, evidence has shown that not all physical activities promote similar effects. In this context, the osteogenic effects of swimming need to be clarified. Objective:To verify and compare total and regional BMD levels between male and female swimming athletes and university non-athletes. METHODS: The sample, composed of 60 participants of both sexes, was divided into two groups: 30 swimming athletes (GA): 15 men $(22.2 \pm 3.92$ years; $73.61 \pm 16.55 \mathrm{~kg} ; 1.76 \pm 0.08 \mathrm{~m})$ and 15 women $(21.91 \pm 2.21$ years; $53.15 \pm 8.36 \mathrm{~kg}$; $1.64 \pm 0.06 \mathrm{~m})$ and a control group (CG): 30 university non-athletes: 15 men $(20.73 \pm 1.27$ years; $74.4 \pm 5.54 \mathrm{~kg}$, $1.74 \pm 0.04 \mathrm{~m}$ ) and 15 women (19.93 \pm 2.05 years; $59.72 \pm 1.33 \mathrm{~kg} ; 1.63 \pm 0.004 \mathrm{~m})$. BMD (total, arms, legs, pelvis and spine) was measured using dual energy $X$-ray absorptiometry (DXA). The results were compared with one-way ANOVA using Scheffé's post hoc test, when necessary. Results: When compared with the women, the men of both groups presented superior results for all BMD values analyzed. In addition, GA had higher BMD of arms and spine when compared to the $C G$, both for males ( $p=0.016$ and $p=0.001$, respectively) and females ( $p=0.0001$ and $p=0.011$, respectively). Conclusions: The results of this study demonstrate that young male adults, athletes and non-athletes, present higher levels of BMD than their peers of the opposite sex. In addition, the results suggest that when undertaken for competitive purposes and with a weekly training volume of 12 hours or more, swimming may be beneficial for the bone development of young athletes when compared to non-athlete controls. Level of evidence III; Retrospective comparative study.
\end{abstract}

Keywords: Osteogenesis; Bone density; Sports; Absorptiometry, photon; Densitometry.

\section{RESUMO}

Introdução: Os efeitos osteogênicos gerados pelas diferentes modalidades esportivas são alvo de um crescente número de investigações. A prática regular de atividades físicas éuma das principais recomendações para a estimulação da densidade mineral óssea (DMO). Entretanto, as evidências têm demonstrado que nem todas as atividades físicas promovem efeitos semelhantes. Nesse contexto, os efeitos osteogênicos da natação precisam ser esclarecidos. Objetivo: Verificar e comparar os níveis de DMO, total e regional, entre atletas de natação de ambos os sexos e universitários não atletas. Métodos: A amostra, composta por 60 participantes de ambos os sexos, foi dividida em dois grupos: 30

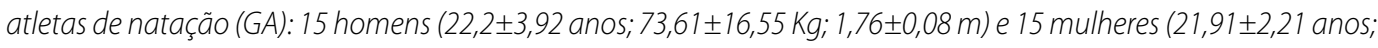

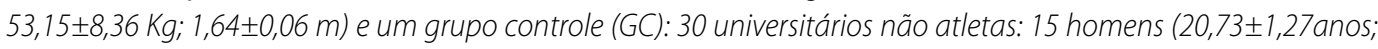

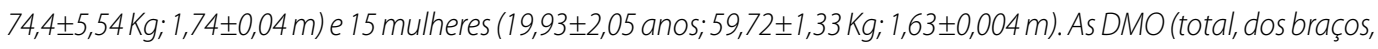
pernas, pelve e coluna) foram medidas com utilização da absorciometria radiológica de dupla energia (DXA). Os resultados foram comparados com auxílio da ANOVA One-Way utilizando, quando necessário, o teste post hoc de Scheffé. Resultados: Quando comparados com as mulheres, os homens dos dois grupos apresentaram resultados superiores para todas as DMO analisadas. Além disso, o GA apresentou maiores DMO de braços e de coluna quando comparado ao GC, tanto para homens ( $p=0,016$ e $p=0,001$, respectivamente) quanto para mulheres ( $p=0,0001 \mathrm{e}$ $p=0,011$, respectivamente). Conclusão: Os resultados do presente estudo demonstram que os jovens adultos do sexo masculino, atletas e não atletas, apresentam maiores níveis de DMO que seus pares do sexo oposto. Além disso, os resultados sugerem que, quando praticado com objetivo competitivo e com volume de treinamento semanal igual ou superior a 12 horas, a natação pode ser benéfica para o desenvolvimento ósseo de jovens atletas, quando comparado com o grupo controle não atletas. Nível de evidência III; Estudo retrospectivo comparativo.

\section{Descritores: Osteogênese; Densidade óssea; Esportes; Absorciometria de fóton; Densitometria.}

\section{RESUMEN}

Introducción: Los efectos osteogénicos generados por las diferentes modalidades deportivas son objeto de un creciente número de investigaciones. La práctica regular de actividades físicas es una de las principales recomendaciones para la estimulación de la densidad mineral ósea (DMO). Entretanto, las evidencias han demostrado que no todas las actividades físicas promueven efectos semejantes. En ese contexto, los efectos osteogénicos de la natación precisan ser esclarecidos. Objetivo: Verificary comparar los niveles de DMO, totaly regional, entre atletas de natación de ambos sexos y universitarios no atletas. Métodos: La muestra, compuesta por 60 participantes de ambos sexos, 
fue dividida en dos grupos: 30 atletas de natación (GA): 15 hombres (22,2 $\pm 3,92$ años; $73,61 \pm 16,55 \mathrm{Kg} ; 1,76 \pm 0,08 \mathrm{~m}$ ) y 15 mujeres (21,91 $\pm 2,21$ años; $53,15 \pm 8,36 \mathrm{Kg} ; 1,64 \pm 0,06 \mathrm{~m}$ ) y un grupo control (GC): 30 universitarios no atletas: 15 hombres $(20,73 \pm 1,27$ años; $74,4 \pm 5,54 \mathrm{Kg} ; 1,74 \pm 0,04 \mathrm{~m})$ y 15 mujeres (19,93 $\pm 2,05$ años; $59,72 \pm 1,33 \mathrm{Kg} ; 1,63 \pm 0,004 \mathrm{~m}$ ). Las DMO (total, de los brazos, piernas, pelvis y columna) fueron medidas con el uso de la absorciometría radiológica de doble energía (DXA). Los resultados fueron comparados con auxilio de ANOVA One-Way utilizando, cuando fuera necesario, el test post hoc de Scheffé. Resultados: Cuando comparados con las mujeres, los hombres de los dos grupos presentaron resultados superiores para todas las DMO analizadas. Además, el GA presentó mayores DMO de brazosy de columna cuando comparado al GC, tanto para hombres ( $p=0,016$ e $p=0,001$, respectivamente) como para mujeres ( $p=0,0001$ y $p=0,011$, respectivamente). Conclusión: Los resultados del presente estudio demuestran que los jóvenes adultos del sexo masculino, atletas y no atletas, presentan mayores niveles de DMO que sus pares del sexo opuesto. Además, los resultados sugieren que, cuando practicado con objetivo competitivo y con volumen de entrenamiento semanal igual o superior a 12 horas, la natación puede ser benéfica para el desarrollo óseo de jóvenes atletas, cuando comparado con el grupo control no atletas. Nivel de evidencia III; Estudio retrospectivo comparativo.

\section{Descriptores: Osteogénesis; Densidad Ósea; Deportes; Absorciometría de fotón; Densitometría.}

\section{INTRODUCTION}

Bone tissue accounts for approximately $18 \%$ of the body weight of a healthy adult male, performing important mechanical and physiological functions. Besides serving as a structural framework for soft tissue support, protecting organs and tissues, and providing attachment points for the tendons of most muscles, the bone skeleton is part of an important lever system, acting as an important stock of minerals, namely calcium and phosphorus. ${ }^{1}$ In fact, almost all of the body's calcium is stored in the bones, and its release into the bloodstream occurs through a negative feedback mechanism.2

Bone mineral density (BMD) in the body, represented by the amount of minerals per square centimeter of bone, is considered an indirect risk indicator for osteoporosis and fractures, thus requiring strict control. ${ }^{3}$

BMD levels are maintained through a harmonious process of calcium formation and resorption in bone tissue mediated by biochemical and mechanical factors. ${ }^{4}$ In this process, the osteoblasts (cells responsible for bone tissue formation) and osteoclasts (cells responsible for bone resorption) act in a balanced manner. However, such a balance can be threatened positively or negatively by two main variables: hormonal changes, as is the case during and after menopause, and by the action of mechanical forces (e.g., compression, impacts, torsion, etc.), promoted by different types of physical activity: occupational, active transport and leisure (sports and exercise), and others. ${ }^{4}$

Due to the importance of the difficulty in controlling and maintaining calcium stores in the body, as is the case during menopause or with aging, the possible and different interventions that effectively help maintain or improve BMD levels take on increasing importance. ${ }^{5}$

In terms of mechanical stimuli, physical activity, especially activities that promote tension, traction or compression loads, is one of the main nonpharmacological resources used to stimulate osteogenesis. ${ }^{3}$

Thus, a growing body of research has shown that people who engage in sports that promote own bodyweight bearing (compressive loads) and/or impacts, associated with muscle contractions (tension loads), such as during running and weightlifting, among others, have higher BMD levels., ${ }^{4,6-10}$ On the other hand, exercises or sports that do not require bodyweight bearing or significant compressive loads, such as swimming and cycling, are associated with lower BMD.,3,611-13

Gómez-Bruton et al. ${ }^{5}$ observed that, in the same way as in the absence of gravity, as with space travel, due to microgravity, swimming has no major osteogenic effects. However, this viewpoint is not consensual. For example, some studies $3,8,13,14$ report that sports that promote low impacts can also offer positive responses to BMD. Along these lines,
Bergman et al. ${ }^{3}$ note that exercises such as swimming, while having fewer osteogenic effects, can reduce the risk of fractures indirectly by maintaining muscle mass and strength. In a recent meta-analysis, Gomez-Bruton et al. ${ }^{15}$ observed that young swimmers, when compared to their peers undertaking more osteogenic sports, in other words, sports that involve moderate or high loads and impacts (e.g., basketball, soccer and running, among others), have lower BMD values. However, when compared with non-athlete controls, swimmers have similar BMD levels in almost all bone areas.

The fact that most studies which have investigated and compared the effects of different types of physical exercise on osteogenic responses were conducted with very young and/or older female subjects ${ }^{4,8,9,14}$ may be one of the reasons for bias during the interpretation of results of studies comparing the effects of different types of physical activity on BMD.

Therefore, although there is a growing body of evidence pointing to a positive relationship between regular physical activity (PA) and bone health, it is still not sufficiently clear whether swimming as a sport is associated with BMD in young adults of both sexes. ${ }^{13,16-18}$

Given the above, the main purpose of this study was to verify and compare the BMD levels of different body areas of swimming athletes of both sexes, comparing them with a control group made up of healthy university non-athletes, with ages and characteristics similar to those of the swimmers.

\section{MATERIALS AND METHODS}

The sample for this study consisted of 60 young adults of both sexes aged between 18 and 30 years (21.04 \pm 2.44 years), selected non-probabilistically at clubs and universities and divided into two groups: 30 amateur swimming athletes (15 men and 15 women) (GA) and control group (CG) composed of 30 young college/university students and non-athletes of both sexes (15 men and 15 women).

Eligibility criteria for participation in the CG were as follows: male and female subjects who had not systematically undertaken (150 or more minutes of physical activity per week) exercise for at least five months, were non-smokers, had not been diagnosed with conditions capable of altering the variables analyzed (e.g., hyperthyroidism, diabetes mellitus, hyperparathyroidism, rheumatoid arthritis, anorexia nervosa, and others), and were not taking drugs capable of influencing BMD (e.g., corticosteroids or vitamin D supplements). In addition, women participating in the CG were not supposed to report a history of menstrual dysfunction within the last 12 months. 
During the composition of the group of athletes (GA), in addition to the abovementioned criteria, the participants had to be swimming athletes for at least 24 months, report training for at least nine weekly hours for the last 12 months and do not engage in any other physical activity except swimming. Inclusion criteria were assessed using a questionnaire. Subjects who did not complete all the stages proposed by the study or those who wished - for any reason and at any time - to withdraw from the study, were excluded from the sample.

All participants signed a free and informed consent form, in accordance with the criteria of Resolution 466/12 of the Brazilian National Board of Health for research involving human subjects. All the stages of the study were approved by the Institutional Review Board of the Universidade Federal de Sergipe (CAAE-0109.0.107.000-08).

Body mass (BM), height (HGT), body composition (BC) and total (TBMD) and regional (RBMD) bone mineral density were measured in all participants.

BM measurements were taken using a mechanical scale (Filizola ${ }^{\oplus}$ - Brazil) with precision of $0.01 \mathrm{~kg}$; HGT was measured with a portable stadiometer (Seca ${ }^{\oplus}$, Baystate Scale \& Systems, USA) with precision of 0.1 $\mathrm{cm}$; BMD was verified using Dual Energy X-ray absorptiometry (DXA) performed with the aid of a scanner (Lunar Radiation Corp. Madison, WII). The software version used was 5.56, provided by the equipment manufacturer. To take the measurements, the hydration value was set (0.732) for lean tissue mass. The validity of the instrument is discussed in detail in other studies. ${ }^{19,20}$

Body composition and BMD were measured using DXA, which enabled us to verify lean body mass and fat mass in addition to TBMD, and the RBMD of the legs, arms, spine and pelvis. The protocol for the DXA evaluation procedure was the one suggested by Roche, Reymsfield and Lohman. ${ }^{21}$ The assessment of body composition in this equipment assumes that lean body mass hydration is $73.2 \%$ with body fat of $17 \% .{ }^{21}$ Regarding reproducibility, coefficients of variation have been estimated for repeated BMD measurements of less than 0.6\% for TBMD; $0.8 \%$ for upper limbs; $0.9 \%$ for upper limbs; $1.7 \%$ for the spine ${ }^{20}$ and $3.3 \%$ for lean tissue. ${ }^{19}$

\section{Statistical analysis}

The Shapiro-Wilk test was used to identify the normality of data distribution. After this stage, the subjects' characteristics were presented via descriptive statistics, using the arithmetic mean (M) as a measure of central tendency and standard deviation (SD) as a measure of variability. To compare total BMD and BMD in the pelvis, spine, arms and legs of the male and female athletes and university students, we used One-Way ANOVA and where necessary Scheffé's post hoc test. All the statistical tests were conducted using the statistical software SPSS ${ }^{\oplus}$ for Windows (version 20.0, 2011, Chicago - USA), adopting a significance level of $\mathrm{p}<0.05$.

\section{RESULTS}

The mean age and physical characteristics of the subjects of both sexes can be seen in Table 1 .

In all the comparisons, the highest intra- and intergroup values for $B M, B M I, H G T$ and lean tissue were observed in males $(p<0.05)$.

\section{Bone Mineral Density (BMD)}

Total and regional BMD results and comparisons of participants in both groups can be seen in Table 2 .

The results presented in Table 2 above demonstrate that the athletes studied had higher arm and spine BMD when compared to the control group individuals with $p$-values $=0.016$ and 0.0001 , respectively, for females and males in BMD of the arms and $p=0.0001$ and 0.011 in the spine BMD.
Table 1. Physical characteristics and age of the sample.

\begin{tabular}{|c|c|c|c|c|c|}
\hline \multirow[b]{2}{*}{ Variables } & \multirow{2}{*}{\begin{tabular}{|c|} 
Total \\
$\mathrm{T}(\mathrm{n}=60)$ \\
$\overline{\boldsymbol{x}} \pm \mathrm{SD}$ \\
\end{tabular}} & \multicolumn{2}{|c|}{ GA } & \multicolumn{2}{|c|}{ CG } \\
\hline & & $\begin{array}{c}\text { Male }(n=15) \\
\bar{x} \pm \text { SD }\end{array}$ & $\begin{array}{c}\text { Fem }(n=15) \\
\bar{x} \pm \text { SD }\end{array}$ & $\begin{array}{c}\text { Male }(n=15) \\
\bar{x} \pm \text { SD }\end{array}$ & $\begin{array}{c}\text { Fem }(n=15) \\
\bar{x} \pm \text { SD }\end{array}$ \\
\hline Age (years) & $21.04 \pm 2.44$ & $22.22 \pm 3.92$ & $21.91 \pm 2.21$ & $20.73 \pm 1.27$ & $19.93 \pm 2.05$ \\
\hline Body mass (kg) & $65.60 \pm 12.09$ & $73.61 \pm 16.55$ & $53.15 \pm 8.36^{£}$ & 74.4 $\pm 5.54 @$ & $59.72 \pm 1.33^{* \#}$ \\
\hline Height (m) & $1.69 \pm 0.08$ & $1.76 \pm 0.08$ & $1.64 \pm 0.06^{ \pm}$ & 1.74 $\pm 0.04 @$ & $1.63 \pm 0.04^{* \#}$ \\
\hline BMI $\left(\mathrm{kg} / \mathrm{m}^{2}\right)$ & $22.63 \pm 2.79$ & $23.54 \pm 4.55$ & $20.24 \pm 2.36^{\ddagger}$ & $24.37 \pm 0.96^{@}$ & $22.33 \pm 1.35$ \\
\hline Lean tissue (kg) & $45.8 \pm 9.67$ & $55.07 \pm 5.90$ & $37.05 \pm 5.14^{£}$ & $53.13 \pm 3.24 @$ & $38.13 \pm 6.37^{* \#}$ \\
\hline $\begin{array}{c}\text { Experience } \\
\text { (years) }\end{array}$ & --- & $6.05 \pm 5.70$ & $4.70 \pm 4.42$ & --- & --- \\
\hline $\begin{array}{l}\text { Frequency } \\
\text { (days/week) }\end{array}$ & --- & $4.30 \pm 1.33$ & $4.10 \pm 1.19$ & --- & --- \\
\hline $\begin{array}{l}\text { Duration of } \\
\text { session (h) }\end{array}$ & --- & $2.5 \pm 0.5$ & $3.10 \pm 0.3^{*}$ & -- & --- \\
\hline
\end{tabular}

$\mathrm{GA}=$ Group of swimming athletes; $\mathrm{CG}=$ control group (non-athletes); $\mathrm{T}=$ all participants; Male. Male; Fem. = Female; $X=$ Mean; $\mathrm{SD}=$ Standard Deviation; $\mathrm{BMI}=$ Body Mass Index; $\mathrm{kg}=$ Kilograms; $\mathrm{m}=$ meters; $\mathrm{h}=$ hours. * *ifference + difference between the female $C G$ and the female $G A, p<0.05$; $£$ difference between the female $G A$ and the + difference between the female $C G$ and the female $G A, p<0.05$; $£$ difference betwe
male $G A, p<0.05$. @ difference between the male $C G$ and the female $G A, p<0.05$.

Table 2. Results of the regional and total BMD of athletes of both sexes.

\begin{tabular}{|c|c|c|c|c|c|}
\hline \multirow[b]{2}{*}{ Variables } & \multirow{2}{*}{$\begin{array}{c}\text { Total } \\
T \text { T }(n=60) \\
\bar{x} \pm S D\end{array}$} & \multicolumn{2}{|c|}{ GA } & \multicolumn{2}{|c|}{ CG } \\
\hline & & $\begin{array}{c}\text { Male } \\
(n=15) \\
\bar{x} \pm \text { SD }\end{array}$ & $\begin{array}{c}\text { Fem } \\
(n=15) \\
\bar{x} \pm S D\end{array}$ & $\begin{array}{c}\text { Male } \\
(\mathrm{n}=15) \\
\bar{x} \pm S D\end{array}$ & $\begin{array}{c}\text { Fem } \\
(\mathrm{n}=15) \\
\overline{\boldsymbol{x}} \pm \mathrm{SD}\end{array}$ \\
\hline TOT BMD $\left(\mathrm{g} / \mathrm{cm}^{2}\right)$ & $1.09 \pm 0.22$ & $1.21 \pm 0.05$ & $1.15 \pm 0.06$ & $1.12 \pm 0.29$ & $0.93 \pm 0.21^{*}$ \\
\hline $\mathrm{LL} B M D\left(\mathrm{~g} / \mathrm{cm}^{2}\right)$ & $1.13 \pm 0.22$ & $1.32 \pm 0.10$ & $1.16 \pm 0.08$ & $1.17 \pm 0.28$ & $0.96 \pm 0.14^{* \#}$ \\
\hline UL BMD $\left(\mathrm{g} / \mathrm{cm}^{2}\right)$ & $0.8 \pm 0.12$ & $0.93 \pm 0.06$ & $0.86 \pm 0.05$ & $0.75 \pm 0.07^{\zeta}$ & $0.73 \pm 0.13^{*+}$ \\
\hline SPI BMD $\left(\mathrm{g} / \mathrm{cm}^{2}\right)$ & $0.96 \pm 0.21$ & $1.11 \pm 0.13$ & $1.16 \pm 0.30$ & $0.88 \pm 0.09^{c}$ & $0.81 \pm 0.09^{*+}$ \\
\hline
\end{tabular}

M= Male: F=Female: $\mathrm{BMD}=$ Bone Mineral Density:TOT BMD = Bone Mineral density of the entire bone skeleton; $L L B M D=$ Bone Mineral density of the lower limbs; UL BMD = Bone Mineral density of the upper limbs; SPI BMD = Bone Mineral density of the spine.

\section{DISCUSSION}

The aim of this study was to verify and compare the BMD of swimming athletes of both sexes with each other and with a population of healthy college/university students who do not engage in regular exercises or sports. The findings presented here differ from the results of previous studies which, after nine months of follow-up, found that, unlike people who practice sports that promote higher compressive and impact forces, such as basketball, regular swimming was not related to increased BMD in athletes. ${ }^{6}$ However, such findings may be due to the age difference between the sample participants, since in the study mentioned the participants were aged 11.9 years on average, which may suggest maturation effects.

The results observed in this study are similar to those obtained by Gómez-Bruton et al.. ${ }^{5}$ who also compared swimmers with their non-athlete peers. As in the current study, the authors found that BMD results between men and women were similar, yet the BMD levels of the arms and spine of the athletes were higher than those of the non-athletes.

Although not within the scope of this present study, it is important to point out that the similarity in BMD between male and female athletes suggests an association between BMD and the type of mechanical stimulus promoted by swimming. After all, studies conducted in microgravity environments ${ }^{22}$ have shown that the greatest bone losses are observed in the bones responsible for bearing the weight of the body, that is, those less exposed to mechanical loads.

Moreover, although the BMD differences may not be relatively substantial, the findings are important given the discovery that a 10\% decrease in BMD may increase the chances of fractures and mortality in older men and women. ${ }^{23}$ Conversely a similar increase in BMD is related to a $50 \%$ decrease in the chance of osteoporosis in women. ${ }^{24}$

Besides the fact that the results observed in this study are different from those found in similar studies available in the literature, ${ }^{5,6,11}$ it is 
important to emphasize that most of the studies indicated showed that swimming has negative or neutral impacts $5,15,25$ on BMD.

In this study, the fact that we found swimmers to have higher BMD levels than their peers who do not engage in regular physical activity reinforces the association between regular physical exercise and BMD of bones most exposed to mechanical loads related to swimming (e.g., humerus, lumbar vertebrae and hip bones). ${ }^{13}$

One of the explanations for the difference between the results of this study and those observed in previous research projects that, however, were not able to find significant differences in BMD between swimmers and subjects who do not practice physical exercise, is linked to variables such as subject age, time performing the activity, and the duration and intensity applied in training sessions. For example, the athletes in this study reported weekly training sessions averaging between 10 and 12 hours, values higher than those found in other studies such as the one undertaken by Hind et al. ${ }^{25}$ and Maïmoun et al., ${ }^{26}$ who, despite having used samples of athletes of similar ages (20 to 25 years), reported less than 10 hours/week of training. Although this difference may seem relatively small, it is worth keeping in mind that for those who train daily ( $5 \times$ week) throughout the month, this difference can be as much as 80 hours.
One of the main limitations of this study is the lack of control of eating habits. Therefore, it is recommended that in future studies such limitations be overcome, in addition to being accompanied by hormonal tests.

\section{CONCLUSIONS}

Young male adults, athletes and non-athletes, have higher BMD levels than their peers of the opposite sex. Moreover, swimming athletes of both sexes, who train with volumes equal to or greater than 12 hours per week, have higher BMD values in the upper limbs and spine when compared to their peers of the same age who do not practice regular physical exercise.

\section{ACKNOWLEDGMENTS}

We are grateful to Diagnose: Centro de Diagnóstico por Imagens de Maceió/Alagoas, represented by Dr. João Bruno, for kindly lending us the DXA test results without which the study would have been impossible. We are also grateful to CAPES for funding the research.

All authors declare no potential conflict of interest related to this article

AUTHORS' CONTRIBUTIONS: Each author made significant individual contributions to this manuscript. RA: writing, review, data interpretation, recruitment of subjects and final approval of the manuscript; AG: writing and review of the manuscript; FF: writing and collaboration in the data analysis; BR: writing of the manuscript; ACCO: assistance in the study design and data interpretation; DNN (0000-0002-6858-3092)*: critical review of the manuscript. All authors reviewed and approved the final version of the manuscript.

\section{REFERENCES}

1. Tortora GJ, Derrickson BD. Principles of anatomy and physiology. 12th ed. USA: John Wiley \& Sons; 2009

2. Jakob F, Seefried L, Ebert R. Pathophysiology of bone metabolism. Internist (Berl). 2008;49(10):1159-60.

3. Bergmann P, Body JJ, Boonen S, Boutsen Y, Devogelaer JP, Goemaere S, et al. Loading and skeletal development and maintenance. J. Osteoporos. 2010;2011:786752.

4. Creighton DL, Morgan AL, Boardley D, Brolinson PG. Weigth-bearing exercise and markers of bone turnover in female athletes. J Appl Physiol (1985). 2001;90(2):565-70.

5. Gómez-Bruton A, González-Agüero A, Gómez-Cabello A, Matute-Llorente A, Casajús JA, Vicente-Rodríguez G. Swimming and bone: is low bone mass due to hypogravity alone or does other physical activity influence it? Osteoporos Int. 2016;27(5):1785-93.

6. Agostinete RR, Lynch KR, Gobbo LA, Lima MC, Ito IH, Luis-de Marco R, et al. Basketball affects bone mineral density accrual in boys more than swimming and other impact sports: 9-mo follow-up. J Clin Densitometry. 2016;19(3):375-381.

7. Nagata M, Kitagawa J, Miytake T, Nakahara Y. Effects of exercise practice on the maintenance of radius bone mineral density in postmenopausal women. J Physiol Anthropol Appl Human Sci. 2002;21(5):229-34.

8. Nunes JF. Força muscular e densidade mineral óssea. Rev Biol Saude (UNISEP). 2008;2(1):87-92.

9. Silva CC, Teixeira AS, Goldberg TB. O esporte e suas implicações na saúde óssea de atletas adolescentes. Rev Bras Med Esporte. 2003;9(6):426-32.

10. Uzunca K, Birtane M, Durmus-Altun G, Ustun F. High bone mineral density in loaded skeletal regions of former Professional football (soccer) players: what is the effect of time after active career? Br J Sports Med. 2005;39(3):154-8.

11. Abrahin O, Rodrigues RP, Marçal AC, Alves EAC, Figueiredo RC, de Sousa EC. Swimming and cycling do not cause positive effects on bone mineral density: a systematic review. Rev Bras Reumatol Engl Ed. 2016;56(4):345-51.

12. Olmedillas H, González-Aguero A, Moreno LA, Casajus JA, Vicente-Rodriguez G. Cycling and bone health: a systematic review. BMC Med. 2012;10:168.

13. van Santen JA, Pereira C, Sanchez-Santo MT, Cooper C, Arden NK. Dominat vs, non-dominant hip comparison in bone density in young sporting athlete. Arch Osteoporos. 2019;25;14(1):54.

14. Torres, LL, César, EP, Paizante, GO. A importância da hidroginástica na prevenção da osteoporose senil em indivíduos do sexo feminino. Rev Meio Amb Saúde. 2006;1(11):29-40.

15. Gómez-Bruton A, Montero-Marin J, González-Agüero A, Gómez-Cabello A, Garcia-Campayo J, Moreno $L A$, et al. Swimming and peak bone mineral density: a systematic review and meta-analysis. J Sports Sci. 2018;36(4):365-77.

16. Guadalupe-Grau A, Fuentes T, Guerra B, Calbet JA. Exercise and bone mass in adults. Sports Med. 2009;39(6):439-68.

17. Moreira LD, Oliveira ML, Lirani-Galvão AP, Marin-Mio Rosângela Villa, Santos, Rodrigo Nolasco dos, et al. Physical exercise and osteoporosis: effects of different types of exercises on bone and physical function of postmenopausal women. Arq Bras Endocrinol Metabol, 2014;58(5):514-22.

18. Valente-Dos-Santos J, Tavares ÓM, Duarte JP, Sousa e Silva PM, Rama LM, Casanova JM, et al Total and regional bone mineral and tissue composition in female adolescente athletes: comparison between volleyball players and swimmers. BMC Pediatr, 2018;18(1):212.

19. Calbet JA, Moysi JS, Dorado C, Rodríguez LP. Bone mineral content and density in professional tennis player. Calcif Tissue Int. 1998;62(6):491-6.

20. Morel J, Combe B, Francisco J, Bernard J. Bone mineral density of 704 amateur sportsmen involved in different physical activities. Osteoporos Int. 2001;12(2):152-7.

21. Roche AF, Heymsfield SB, Lohman TG. Human body composition. Champaign IL: Human Kinetics, 1996.

22. Orwoll ES, Adler RA, Amim S, Binkley N, Lewiecki EM, Petak SM, et al. Skeletal health in long-duration astronauts: nature, assessment, and management recommendations from the NASA Bone Summit. J Bone Miner Res. 2013;28(6):1243-55.

23. Bonjour JP, Chevalley T, Ferrari S, Rizzoli R. The importance and relevance of peak bone mass in the prevalence of osteoporosis. Salud Publica Mex. 2009;51(Suppl1):S5-17.

24. Smith MC, Vogel, JM, Whittle MW. Bone mineral measurement. Experiment M078. In: Johnston RS, Dietlein LF (ed). Biomedical results from Skylab. NASA SP-377. Washington, DC.1977. p. 183-90.

25. Hind K, Gannon L, Whatley E, Cooke C, Truscott J. Bone cross-sectional geometry in male runners, gymnasts, swimmers and non-athletic controls: A hip-structural analysis study. Eur J Appl Physiol. 2012;112(2):535-41.

26. Maïmoun L, Mariano-Goulart D, Couret I, Manetta J, Peruchon E, Micallef JP, et al. Effects of physical activities that induce moderate external loading on bone metabolism in male athletes. J Sports Sci. 2004;22(9):875-83. 